\title{
INSTRUMENTS OF THE STATE REGULATION OF FOOD INDUSTRY OF UKRAINE
}

\author{
V. Khrypiuk \\ National University of Food Technologies
}

\begin{tabular}{l}
\multicolumn{1}{c}{ Key words: } \\
Food industry \\
State regulation \\
Instruments of state \\
regulation \\
\hline \multicolumn{1}{c}{ Article history: } \\
Received 11.05.2018 \\
Received in revised form \\
30.05.2018 \\
Accepted 15.06.2018 \\
\hline
\end{tabular}

Corresponding author:

V. Khrypiuk

E-mail:

npnuht@ukr.net

\begin{abstract}
Scientific and methodical principles of state regulation of food industry of Ukraine have been considered in the article. It has been studied, that food industry is not an independently regulated branch of the national economy due to its specific features and it is not able to provide an appropriate international level of quality and safety of food products independently.

Therefore, in connection with the accession to the WTO and the European integration orientation of Ukraine, the question of state regulation of the development of food industry rises sharply.

In this context, it is determined that state regulation is carried out in certain forms and methods, which are reflected in the instruments to achieve the goals. The essence of the concept "instrument" has been determined and it has been established that the set of tools to influence on economic entities varies depending on the economic task, desired result, material capacity and existing experience of regulation. Moreover, the spectrum of the use of state regulation tools is constantly expanding.
\end{abstract}

The classification of instruments (administrative, economic, financial, socio-economic, investment-innovation and political) has been offered, based on the goals, content, nature and means of implementation in conjunction with market selfregulation. With their help the state will be able to regulate food industry, creating conditions for more effective socioeconomic development of the country. A concrete list of instruments of each formed group for the effective regulation of food industry through a detailed analysis of the essence and concept of each of them has been formed.

Attention was paid to the delineation of the instruments of state regulation to be very conditional. That is why any economic, social, political regulator carries an element of administration, and the adoption of any administrative laws and decisions has the purpose of obtaining certain economic and social effect.

It has been proved that only on the basis of a coherent and mutually coordinated action of various instruments of state regulation it is possible to achieve the goal of effective functioning of food industry.

DOI: $10.24263 / 2225-2924-2018-24-3-6$ 


\section{ІНСТРУМЕНТИ ДЕРЖАВНОГО РЕГУЛЮВАННЯ ХАРЧОВОЇ ПРОМИСЛОВОСТІ УКРАЇНИ}

\section{В.I. Хрип'юк}

Національний університет харчових технологій

У статті розглянуто науково-методичні засади державного регулювання харчової промисловості України. Досліджено, щчо харчова промисловість через притаманні ій специфічні особливості не є самостійно регульованою галуззю начіонального господарства та не здатна самостійно забезпечити відповідний міжнародний рівень якості й безпечності харчових продуктів. У зв'язку з вступом у СОТ та євроінтеграційною орієнтаџією України гостро постає питання державного регулювання розвитку харчової промисловості.

У иьому контексті визначено, що державне регулювання здійснюється в певних формах і методах, які знаходять своє відображення в інструментах досягнення иілей. Розкрито сутність поняття «інструмент» та встановлено, що набір інструментів за допомогою яких держава здійснює вплив на суб'єкти господарювання, змінюється залежно від економічного завдання, бажаного результату, матеріальної можливості та існуючого досвіду регулювання. При чому спектр застосування інструментів державного регулювання постійно розширюється.

Запропоновано класифікачію інструментів (адміністративні, економічнофінансові, соиіально-економічні, інвестиційно-інновачійні та політичні), за допомогою яких на основі поставленої мети, змісту, характеру та засобів реалізачії у поєднанні з ринковим саморегулюванням держава зможе проводити регуляторну діяльність харчової промисловості, створюючи передумови більш ефективного сочіально-економічного розвитку краӥни. Представлено конкретний перелік інструментів кожної сформованої групи для ефективного регулювання харчової промисловості, детальний аналіз сутності та поняття кожного із них.

Акцентовано увагу, що розмежування інструментів державного регулювання на запропоновані групи є досить умовним, тому будь-який економічний, соиіальний, політичний регулятор несе у собі елемент адміністрування, а прийняття будь-яких адміністративних законів $і$ рімень має на меті отримання певного економічного та соціального ефекту.

Доведено, що тільки на основі иілісної та взаємоузгодженої дії різноманітних інструментів державного регулювання можливе досягнення мети ефективного функиіонування харчової промисловості.

Ключові слова: харчова промисловість, державне регулювання, інструменти державного регулювання.

Постановка проблеми. Сучасний економічний розвиток національної господарства будь-якої країни світу потребує активної регулювальної діяльності з боку держави. Забезпечуючи продовольчу безпеку країни, розвиток 
харчової промисловості набуває неабиякої стратегічної важливості та пріоритетності серед інших галузей національного господарства. На жаль, ринковий механізм саморегулювання України не в змозі забезпечити відповідну якість i достатню конкурентоспроможність продуктам харчування для виходу на міжнародні ринки у перспективі із сучасним євроінтеграційним напрямком розвитку. Тому діяльність виробників продуктів харчування потребує відповідного державної підтримки та коригувальних дій з боку держави. Розв'язання поставленої проблеми полягає у визначенні та науковому обгрунтуванні інструментів, за допомогою яких у поєднанні з ринковим саморегулюванням держава зможе проводити регуляторну діяльність харчової промисловості, вирішуючи важливі питання соціально-економічного розвитку країни.

Аналіз останніх досліджень і публікацій. Особливості впливу держави на підприємства харчової промисловості досладжували такі українські економісти, як С.О Гуткевич, А.О. Заїнчковський, М.П. Сичевський. Пошуку оптимального набору функціонуючих інструментів державного регулювання, які застосовуються в харчовій промисловості, присвячені наукові праці М.А. Мiненка, Г.Г. Тараненко, Н.А. Тюхтенко, М.І. Сахацького. Високо оцінуючи їх науковий вклад, варто зазначити, що незважаючи на існування ряду теоретичних і методологічних досліджень державного регулювання в галузі харчової промисловості, інструменти, які використовуються державою для здійснення відповідного впливу з метою сприяння розвитку інституційних осередків харчової промисловості, до теперішнього часу повністю не вивчено.

Мета статті полягає у комплексному дослідженні й аналізі основних інструментів державного регулювання харчової промисловості, визначенні їх сутності для подальшого покращення державного регулювання економічного розвитку.

Викладення основних результатів дослідження. Специфіка та значущість харчової промисловості України вимагає від органів державної влади особливої уваги. Регулювання процесів відтворення в харчовій галузі в поєднанні з ринковим механізмом сприятиме ефективному розвитку національної економіки країни. С.О Гуткевич. [1, с. 4] та М.А. Міненко [2, с. 5051], досліджуючи поняття «державного регулювання» в площині харчової промисловості, визначають, що це діяльність органів державної влади, які за допомогою норм і методів регламентують діяльність суб'єктів господарювання через систему правових, економічних та інституційних інструментів державного регулювання.

Отже, державне регулювання - це дія держави, а інструмент (лат. instrumentum) - знаряддя, засіб, певні прийоми, за допомогою яких державні органи здійснюють цю дію, тобто вплив на суб'єкти економічних відносин 3 метою реалізації поставлених завдань і мети [3, с. 48].

Державні інструменти впливу на розвиток галузей економіки можуть бути найрізноманітнішими. Набір інструментів змінюється залежно від економічного завдання, бажаного результату, матеріальної можливості держави та існуючого досвіду регулювання. Спектр застосування інструментів державного регулювання постійно розширюється. 
Економісти зазначають [4, с. 53], що здійснення однієї і тієї ж функції держави можливе за допомогою різних інструментів, головне завдання держави полягає в оптимальному їх поєднанні. При цьому оптимальним варіантом $\epsilon$ ефективне поєднання інструментів державного регулювання та принципів функціонування вільного ринку для розвитку національного виробництва, забезпечення продовольчої безпеки та соціальної підтримки населення сільських територій.

Варто зазначити, що в існуючих на сьогодні наукових дослідженнях, які стосуються державного регулювання харчової промисловості, не має чіткого науково обгрунтованого переліку інструментів, за допомогою яких держава впливає саме на розвиток харчової промисловості. Більшість досліджень стосуються пошуку інструментів державного регулювання галузей національного господарства, в тому числі аграрної сфери, частиною якої є харчова промисловість, тобто інструменти формуються на загальній основі.

Орієнтуючись на загальні дослідження широкого кола державних інструментів і специфічність харчової промисловості, розподілимо інструменти залежно від поставленої мети, змісту, характеру та засобів реалізації на адміністративні, економічно-фінансові, соціально-економічні, інвестиційноінноваційні та політичні, визначивши основні складові кожної групи (рис.).

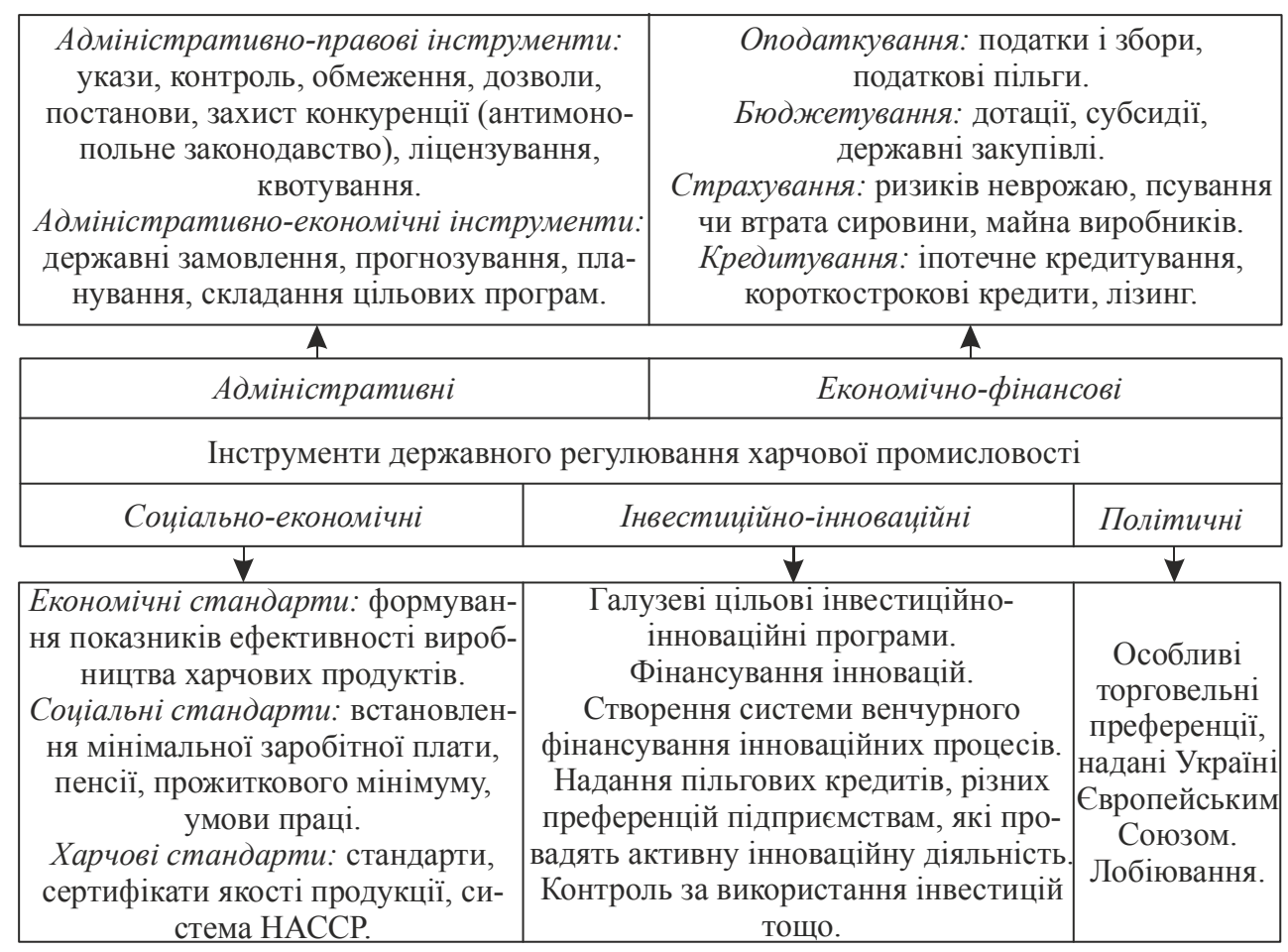

Рис. Інструменти державного регулювання харчової промисловості, складено автором на основі проведеного дослідження

Перша група інструментів державного регулювання формується на основі здійснення адміністративних методів державного регулювання. Адміністра- 
тивні інструменти державного регулювання можна поділити на адміністративно-правові й адміністративно-економічні.

Адміністративно-правові інструменти передбачають розробку та затвердження нормативно-правової бази законодавства, на основі якого провадять свою діяльність усі об’єкти харчової промисловості України. Адміністративно-правовий інструментарій являє собою закони, нормативні акти, рішення, постанови, розроблені регламенти, стандарти, санітарні норми, що формують правове середовище державної регуляторної діяльності, встановлюють правила, умови, обмеження, заборони діяльності суб’єктів господарювання та утворюють систему контролю й відповідальності за їх порушення. Інструменти зазначеної підгрупи здійснюють прямий вплив на ринкові відносини та їх учасників, створюючи при цьому конкурентні умови господарювання із забезпеченням захисту національних інтересів. До них також відноситься ліцензування, квотування та антимонопольне законодавство, захист конкуренції.

Ліцензування - це встановлення обмеження на можливість провадити свою господарську діяльність у тій чи іншій галузі. Залежно від важливості галузі в забезпеченні економічної, соціальної, та продовольчої безпеки держава має вимагати від підприємств відповідної кваліфікації та досвіду роботи персоналу, забезпечення певних специфічних умов виробництва, зберігання та продажу продукції тощо. В харчовій промисловості отримання обов'язкової ліцензії необхідне виробникам пива, алкогольних напоїв, спирту етилового, коньячного й плодового, а також тютюнових виробів.

Встановлення квоти на експорт/імпорт певного виду товарів, серед яких може бути продукція харчової промисловості, здійснюється з метою досягнення таких цілей:

- встановлення прямого обмеження частки підприємців-монополістів у виробництві, реалізації товарів на внутрішньому ринку;

- сприяння власному виробництву та розвитку вітчизняних виробників через ризик просування на українському ринку більш дешевшої іноземної продукції. У цьому сенсі квотування є ефективним інструментом захисту національного виробника.

Антимонопольне законодавство як адміністративний інструмент державного регулювання запобігає формуванню монополій, регулює діяльність монополістів і захищає економічну конкуренцію. У сучасному світі законодавче встановлення правил конкуренції належить до найважливіших інструментів впливу держави на економіку. Значення законодавства про захист конкуренції випливає з їі місця в системі ринкового господарювання. Сьогодні ні в кого не виникає сумніву, що конкуренція - двигун економіки. Саме вільне змагання підприємців з метою набуття за рахунок власних досягнень переваг над іншими створює ряд важливих умов успішного поступу суспільства.

В Україні антимонопольне регулювання здійснює спеціальний державний орган - Антимонопольний комітет, який має представництва у всіх регіонах і підконтрольний Президенту України та підзвітний Верховній Раді України.

Необхідність у такому регулюванні обумовлена прагненням держави обмежити ринкову владу монополістів, підвищити ефективність суспільного 
виробництва, захистити споживача і підтримати стандарти якості та безпечності продукції.

Адміністративно-економічні інструменти державного регулювання $\epsilon$ регуляторами, що регламентують вимоги до організації здійснення господарської діяльності, встановлення правил і норм, які мають адміністративний характер з економічним підгрунтям. До них відносяться:

1. Державне замовлення - це інструмент державного регулювання, який за допомогою конкурсу і на контрактній основі формує склад та обсяг товару робіт чи послуг, який необхідний для забезпечення пріоритетних потреб держави. При цьому державними замовниками виступають Верховна Рада України та інші похідні від неї органи державної влади, яким делеговано такі повноваження.

Під пріоритетними державними потребами розуміють потреби України в товарах, роботах і послугах, які необхідні для розв'язання найважливіших соціально-економічних проблем та $є$ ключовими у визначенні державного замовлення як інструменту державного регулювання. Державні замовлення фінансуються, зазвичай, коштами підприємства, а з боку держави можливе надання додаткових пільг (зниження ставки податку, кредитування, гарантування ринку збуту тощо).

2. Ефективними адміністративно-економічними інструментами державного регулювання харчової промисловості можна визначити прогнозування та планування соціально-економічного розвитку, яке здійснюється з метою створення та розробки державних цільових програм, зокрема в харчовій промисловості.

Це здійснюється перш за все на основі науково- й економічно-обгрунтованих прогнозів розвитку окремих галузей, складання планів розподілу цільового фінансування державних чи інвестиційних ресурсів, здійснення державних замовлень, формування державних програм скорочення неефективних галузей харчової промисловості, створення сприятливого клімату в окремих регіонах з метою залучення приватних інвестицій, шляхом вливання державних коштів у розвиток інфраструктури регіону.

Під прогнозом розвитку харчової галузі розуміють науково-обгрунтоване судження про можливий стан галузі в майбутньому та про альтернативні варіанти iі розвитку, які математично прораховані з огляду на необхідний обсяг продукції та передбачений на неї попит. Сформовані прогнози та розрахунки використовуються для складання плану економічно-соціального розвитку галузей економіки.

Другу групу важелів державного впливу на харчову промисловість формують економічно-фінансові інструменти державного регулювання.

Одним із найвпливовіших економічно-фінансових інструментів державного регулювання харчової промисловості, як і інших галузей економіки в цілому, є оподаткування.

Правовою основою податкового регулювання $\epsilon$ Податковий кодекс України [5], який регулює відносини, що виникають у сфері справляння податків і зборів, зокрема визначає вичерпний їх перелік, що справляються в Україні, та порядок їх адміністрування, платників податків і зборів, їхні права 
та обов'язки, компетенцію контролюючих органів, повноваження й обов'язки їхніх посадових осіб під час адміністрування податків, а також відповідальність за порушення податкового законодавства.

Для здійснення ефективної державно-економічної політики податкова система передбачає використання у механізмі податкового регулювання певних податкових пільг. До податкових пільг, що за своєю суттю $є$ можливістю платника податку його не сплачувати, відносяться: неоподатковуваний мінімум, звільнення від сплати податку окремих категорій платників податку, зниження ставки оподаткування, податковий кредит.

Бюджетування як економічно-фінансовий інструмент державного регулювання засноване на використанні ресурсів державного бюджету у вигляді асигнувань у національну економіку і соціально-культурну сферу.

Використання бюджетування як інструменту державного регулювання має на меті підтримку розвитку галузей економіки, виробництв і сфер діяльності, невигідних з точки зору ринку, але необхідних для суспільства в цілому. До бюджетних інструментів державного регулювання відносяться: дотації, субсидії, державні закупівлі.

Мета виплати державних дотацій полягає в забезпеченні можливості населення в доступі до товарів першої необхідності, контролюючи рівень цін на ці товари. Дотації доцільно виплачувати в тих галузях, в яких витрати перевищують рівень ринкової ціни, але в той же час ці галузі вкрай необхідні для розвитку національної економіки. Дотації мають вимушений характер, держава виплачує їх лише тому, що інакше економічні втрати будуть ще більші. Результатом застосування цього інструменту регулювання $\epsilon$ те, що кінцевий споживач отримує більш дешеву продукцію, а виробник цієї продукції - дохід у повному обсязі.

Коло виробництв і галузей, що дотуються, обмежене. Що стосується харчової промисловості України, то виробники окремих видів харчової продукції часто отримують підтримку держави у вигляді дотацій.

Субсидія - це виплати коштів 3 державного або місцевого бюджету для оперативного вирішення фінансових проблем як підприємств, так і населення. На відміну від дотацій, субсидії $є$ або одноразовими виплатами, або обмеженими в часі. Головний критерій при виділенні субсидій підприємству $є$ зацікавленість держави в продовженні функціонування і його розвитку. Категорія державних субсидій поєднує в собі виплати, пов'язані з виробництвом, певним видом продукції та виробничими ресурсами [6, с. 30]. Проте в умовах дефіциту державного бюджету така міра в Україні не одержала свого широкого застосування

Більш поширений та ефективний фінансово-економічний інструмент державного регулювання - це державна закупівля, придбання замовником товарів, робіт і послуг за державні кошти.

Державні закупівлі, норми про які закріплені у Законі України «Про публічні закупівлі», здійснюються майже у всіх випадках придбання товарів, робіт і послуг за кошти державного та місцевого бюджетів, виконання контракту повністю фінансується ресурсами наданими державою та підпадають під державний контроль за їх використанням. 
Світова практика свідчить, що потужним інструментом державного регулювання ризиків є його страхування. Державне регулювання у цій сфері полягає в заохоченні виробників харчових галузей страхувати свої ризики (отримання збитків від неврожаю, псування чи втрати сировини, тварин, птиці, майна виробників).

Відносини у сфері страхування виробників харчової продукції з метою захисту майнових інтересів та забезпечення стабільності виробництва регулюються на основі Закону України «Про особливості страхування сільськогосподарської продукції з державною підтримкою».

Забезпечення виробників харчової продукції достатнім рівнем фінансових ресурсів сприятиме оптимальному розвитку промисловості. На сьогодні $\epsilon$ фактом дефіцит власних фінансових ресурсів у більшості підприємств харчового виробництва. Виробникам залишається лише мріяти про вільний доступ до кредитних коштів. Банки не готові віддавати свої ресурси на кредитування довгострокових капіталовкладень виробників через великий ризик та малу рентабельність виробництва. Іпотечні кредити та кредити на інвестиційну діяльність видаються тільки великим виробникам-монополістам у галузі, тому що більш дрібні підприємства не мають можливості оплачувати великі відсотки за користування позиковими коштами, що, зазвичай, призводить до збанкрутування підприємства.

Роль держави в цій ситуації полягає у створенні умов для збільшення зацікавленості комерційних банків у співпраці з виробниками харчової продукції.

Система норм і стандартів мають адміністративний характер, тому що в цих документах чітко прописані вимоги та умови, яким повинні відповідати суб'єкти господарської діяльності та їхня продукція. Оскільки створення таких документів забезпечує захист і безпеку споживачів продукції, регулювання відносин у сфері якості продукції, охорону довкілля, соціального захисту населення, то ці регуляторні інструменти відносяться до соціальноекономічної групи.

Інструменти державного регулювання харчової промисловості соціальноекономічної групи можна поділити на:

- економічні стандарти та нормативи, які формують показники ефективності виробництва харчових продуктів: норми рентабельності, енерго-, праце-, матеріаломісткості продукції;

- соціальні стандарти - встановлені державою нормативи у сфері соціальних відносин (мінімальна заробітна плата, пенсія, рівень прожиткового мінімуму, тривалість робочого тижня, умови праці), які впливають на матеріальне забезпечення населення, а це, у свою чергу, впливає на можливість раціонально збалансованого харчування.

Інструменти державного регулювання встановлення соціальних стандартів заслуговують особливої уваги, оскільки для України питання забезпечення харчовими продуктами бідніших верств населення $\epsilon$ надзвичайно актуальним. Регулятивні дії з боку держави необхідно спрямовувати на підвищення стандартів життя населення, поліпшення його якості. Це, у в свою чергу, призведе до збільшення купівельної спроможності населення та більш якісного та збалансованого харчування. 


\section{Харчові стандарти — вимоги щодо якості та безпечності продуктів харчування.}

Оскільки у харчовій промисловості одна з головних вимог споживача безпечність харчових продуктів для життя і здоров'я людини, дотримання стандартів та ефективного контролю якості і безпечності харчових продуктів $\epsilon$ основним соціально-економічним інструментом державного регулювання.

Згідно із законодавством України харчові продукти повинні відповідати мінімальним параметрам безпечності та специфікаціям якості, встановленим відповідними органами державного контролю. Одним 3 інструментів досягнення відповідності мінімальним параметрам безпечності є система НАССР.

Загальна вимога обов'язкового запровадження системи НАССР виробниками харчових продуктів встановлена в новій редакції Закону України «Про основні принципи та вимоги до безпечності та якості харчових продуктів» [7], ухваленого Верховною Радою України 20 вересня 2015 року.

Закон має на меті гармонізацію законодавства України із законодавством ЄC у сфері безпечності та якості харчових продуктів, забезпечення високого рівня захисту здоров'я людей та інтересів споживачів, а також створення прозорих умов ведення господарської діяльності, підвищення конкурентоспроможності вітчизняних харчових продуктів. Сьогодні європейська система безпечності харчових продуктів визнана однією 3 найкращих у світі, а європейський споживач $є$ найбільш захищеним. Водночас харчове законодавство ЄС є прикладом осмисленого підходу, що враховує інтереси всіх, хто пов'язаний з ринком харчових продуктів.

Система НАССР є єдиною системою забезпечення безпеки харчової продукції, принципи якої довели свою ефективність і прийняті міжнародними організаціями [8, с. 8]. Основної метою впровадження системи НАССР є забезпечення безпеки харчових продуктів на всіх етапах харчового ланцюга «від лану до столу».

Це надасть можливість вітчизняним виробникам випускати продукти харчування 3 високою доданою вартістю, забезпечивши їм високий рівень стійкого та ефективного економічного розвитку та конкурентоспроможність як на внутрішньому, так і зовнішньому ринках.

Четверту групу «Інструменти державного регулювання харчової промисловості» формують інвестиційно-інноваційні інструменти. Нині інновації стають вирішальним чинником забезпечення довгострокових конкурентних переваг вітчизняних підприємств, а на їх впровадження у підприємств не вистачає інвестиційного забезпечення.

А.О. Заїнчковський і М.П. Сичевський [9, с. 25] визначають, що підвищення конкурентоспроможності продукції, тобто досягнення відповідної якості за вимогами світових стандартів при відносно низькій ціні, можливе лише через впровадження сучасного новітнього обладнання, ефективних методів організації праці та інноваційно-інвестиційного розвитку виробництва. А це, у свою чергу потребує державної підтримки через прийняття відповідних законодавчих i нормативних документів, якими повинно бути передбачено стимулювання інноваційних процесів створення сприятливих умов для вітчизняних та іноземних інвестицій. 
Інноваційна діяльність підприємств вимагає значних капіталовкладень, яких, на жаль, немає у вітчизняних виробників. Вони неспроможні забезпечити інноваційний розвиток свого підприємства власними коштами. Тому регуляторна роль держави в наданні підтримки інноваційно-активним підприємствам $€$ надзвичайно важлива.

Держава може застосовувати різні інструменти державного регулювання для підтримки інноваційного розвитку сучасних підприємств (галузеві цільові інвестиційно-інноваційні програми, фінансування інновацій, контроль за використання інвестицій, створення системи венчурного фінансування інноваційних процесів, надання пільгових кредитів, різних преференцій підприємствам, які провадять інноваційну діяльність, інвестування за рахунок бюджетних коштів, перспективні інноваційні проекти тощо).

Також на увагу заслуговують інструменти п'ятої групи - політичні інструменти державного регулювання харчової промисловості України. До них відносяться надання Україні особливих торговельних преференцій Європейським Союзам, а також політичне лобіювання бізнесових інтересів виробників харчової продукції.

Автономні торговельні преференції Україна отримує шляхом надання ій особливого статусу. Зокрема, преференційний режим торгівлі передбачає зниження ставок мита для поставок українських товарів, а також встановлення квот на такі поставки, що дасть змогу вітчизняним експортерам збільшити поставки на ринки ЄС. Українські виробники отримають можливість завозити певні обсяги товарів без справляння ввізних мит. Зниження ставок мита, а в подальшій перспективі скасування митного оподаткування, 3 метою реалізації зони вільної торгівлі між Україною та ЄС відбувається на основі Угоди про асоціацію.

Іншим важливим політичним інструментом державного регулювання $€$ лобіювання інтересів. Лобіювання - це процес впливу груп, які сформовано навколо спільних інтересів, на владу для ухвалення певних нормативноправових актів або рішень [10].

Йдеться про те, що лобіювання - це, швидше, не вплив держави, а, навпаки, вплив об'єднаних груп виробників на рішення влади. Проте в цих переговорах кінцеве рішення залишається за органами державної влади, тому лобіювання можна віднести до політичних інструментів державного регулювання.

У розвинутих країнах, таких як США, Японії та багатьох інших, лобіювання закріплено на законодавчому рівні та має позитивний вплив на ринкову економіку. В Україні, на жаль, процес лобіювання на законодавчому рівні політично неврегульований і дія таких інструменті викликає досить скептичне ставлення, подекуди лобіювання пов'язане 3 хабарництвом, шантажем. Проте лобізм має і певне позитивне значення, оскільки посилює легітимність парламенту, підвищує ефективність прийняття рішень, діяння влади спрямовується на інтереси виробників, сприяє їх розвитку, що, у свою чергу, робить значний вклад у розвиток національної економіки. Існування такого політичного явища, як лобіювання групових інтересів, у демократичних суспільствах $\epsilon$ невід'ємною його частиною. 
Розмежування інструментів державного регулювання на адміністративні, фінансово-економічні, соціально-економічні, інвестиційно-інноваційні та політичні є досить умовним. Будь-який економічний, соціальний, політичний регулятор несе в собі елемент адміністрування, тому що його контролює певна адміністративна служба. А прийняття адміністративних законів і рішень має на меті отримання певного економічного й соціального ефекту.

\section{Висновки}

Підсумовуючи вищевикладене, можна зробити висновок, що ефективність державного регулювання харчової промисловості України залежить від обраних дієвих інструментів та оптимального їх поєднання. На основі цілісної та взаємоузгодженої дії різноманітних інструментів державного регулювання можливе досягнення мети ефективного функціонування харчової промисловості.

\section{Література}

1. Гуткевич С.О. До питання регулювання інвестиційного процесу / С.О. Гуткевич // Міжнародна економічна діяльність країни в глобальній економіці : матеріали наук. семінару / за ред. проф. Гуткевич С.О. — Київ : НУХТ. — 2017. — Вип. 12. — Ч. 1. — C. $4-6$.

2. Міненко М.A. Регулювання господарської діяльності галузей національної економіки / М.А. Міненко // Наукові праці Національного університету харчових технологій. 2017. — Т. 23, № 3. - С. 49-57.

3. Тюхтенко Н.А. Інструменти та методи регулювання сільськогосподарського виробництва / Н.А. Тюхтенко, С.А. Карунос // Вісник Бердянського університету менеджменту і бізнесу. - 2011. - № 1(13). - С. 47-50.

4. Тараненко Г.Г. Сучасні підходи до державного регулювання продовольчої політики / Г.Г. Тараненко // Інтелект ХХІ. - 2015. - № 1. - С. 50-55.

5. Кодекс України «Податковий кодекс України» від 02.12.2010 № 2755-VI: станом на 20 березня 2018 року [Електронний ресурс]. — Режим доступу : http://zakon3.rada.gov.ua.

6. Сахацький M.I. Інструменти державної підтримки експортного потенціалу аграрних підприємств України / М. Сахацький, І. Ксьонжик // Економічний часопис Східноєвропейського національного університету імені Лесі Українки. - 2016. - № 2. - С. 29-36.

7. Закон України «Про основні принципи та вимоги до безпечності та якості харчових продуктів» від 23.12.1997 № 771/97-ВР: станом на 25 березня 2018 року [Електронний peсурс]. — Режим доступу : http://zakon3.rada.gov.ua.

8. Василенко Г. Посібник для малих та середніх підприємств м'ясопереробної галузі 3 підготовки та впровадження системи управління безпечністю харчових продуктів на основі концепції НАССР [Текст] / Г. Василенко, О. Дорофєєва, Б. Голуб, Г. Миронюк. Київ : Міжнародний інститут безпеки та якості харчових продуктів (IIFSQ). — 2011. $236 \mathrm{c}$.

9. Заӥнчковський А.О. Стан і перспективи розвитку підприємств харчової та переробної промисловості України / А.О. Заїнчковський, М.П. Сичевський // Вісник соціально-економічних досліджень. - 2011. - № 2. - С. 22-26.

10. Нестерович В.Ф. Конституційно-правові засади інституту лобіювання: зарубіжний досвід та перспективи для України: монографія/ В.Ф. Нестерович// МВС України, Луган. держ. ун-т внутріш. справ ім. Е.О. Дідоренка. - Луганськ : РВВ ЛДУВС ім. Е.О. Дідоренка, 2010. - $752 \mathrm{c}$. 